\title{
The myth about the origin of the Karo House
}

\author{
JUARA R. GINTING
}

\begin{abstract}
The Karo people in North Sumatra (Indonesia) consider areas in the Karo regency and those in other regencies as part of Taneh Karo (the Karolands), despite the fact that these areas comprise different administrative territories. This paper focuses on how the idea of Taneh Karo is articulated in a special Karo myth. Scholarly research has discovered that the notion of Taneh Karo originated in pre-colonial times, but an analysis of a local myth which established the concept of Taneh Karo remains an interesting anthropological study. This study is significant as it endeavours to comprehend the traditional ways of life of the Karo people, and it is a crucial attempt to map out the inter-group relations in the Karo area, where the Acehnese, the Batak, and the Malay people take part. It is interesting to note that the myth of Karo has positioned the Karo community and land in a distinctive site within the network of inter-related groups. This is precisely the position which would determine the formation of the Karolands.

KEYWORDS

Myth, ritual, inauguration, performance, wedding, inter-group, clan, patrilineal, regency, domain, pre-colonial, network.
\end{abstract}

\section{INTRODUCTION}

This paper discusses how a Karo myth expresses the concept of the Karolands (Taneh Karo). At present, Taneh Karo forms part of the province of North Sumatra (Indonesia). Some of the original Taneh Karo territory is now situated in the Karo regency (Kabupaten Karo) and the rest has been split up among the regencies of Simalungun, Dairi, Langkat and Deliserdang as well as the municipality of Medan (see Figure 1). In spite of the incorporation of the lands into different governmental administrative territories, Karo people still feel that these parts are related to each other as Taneh Karo. Karo people consider

JUARA R. GINTING is a lecturer in Cultural Anthropology at USU (Universitas Sumatera Utara), Medan. He obtained his MA from Leiden University, the Netherlands (1994). He studied at the Westfälische Wilhelms-Universität in Münster, Germany on a grant from DAAD (1995). His research on the Karo of North Sumatra focuses on a wide range of themes. Juara R. Ginting may be contacted at: juara_ginting@yahoo.co.uk.

(C) 2010 Faculty of Humanities, University of Indonesia 
the upper parts of the Langkat and Deliserdang regencies as well as the upper parts of Medan municipality as Karo Jahe (Downstream Karo) and those parts of Taneh Karo that have become part of the territory of the regencies of Karo, Simalungun and Dairi as Karo Gugung (Karo Highlands).

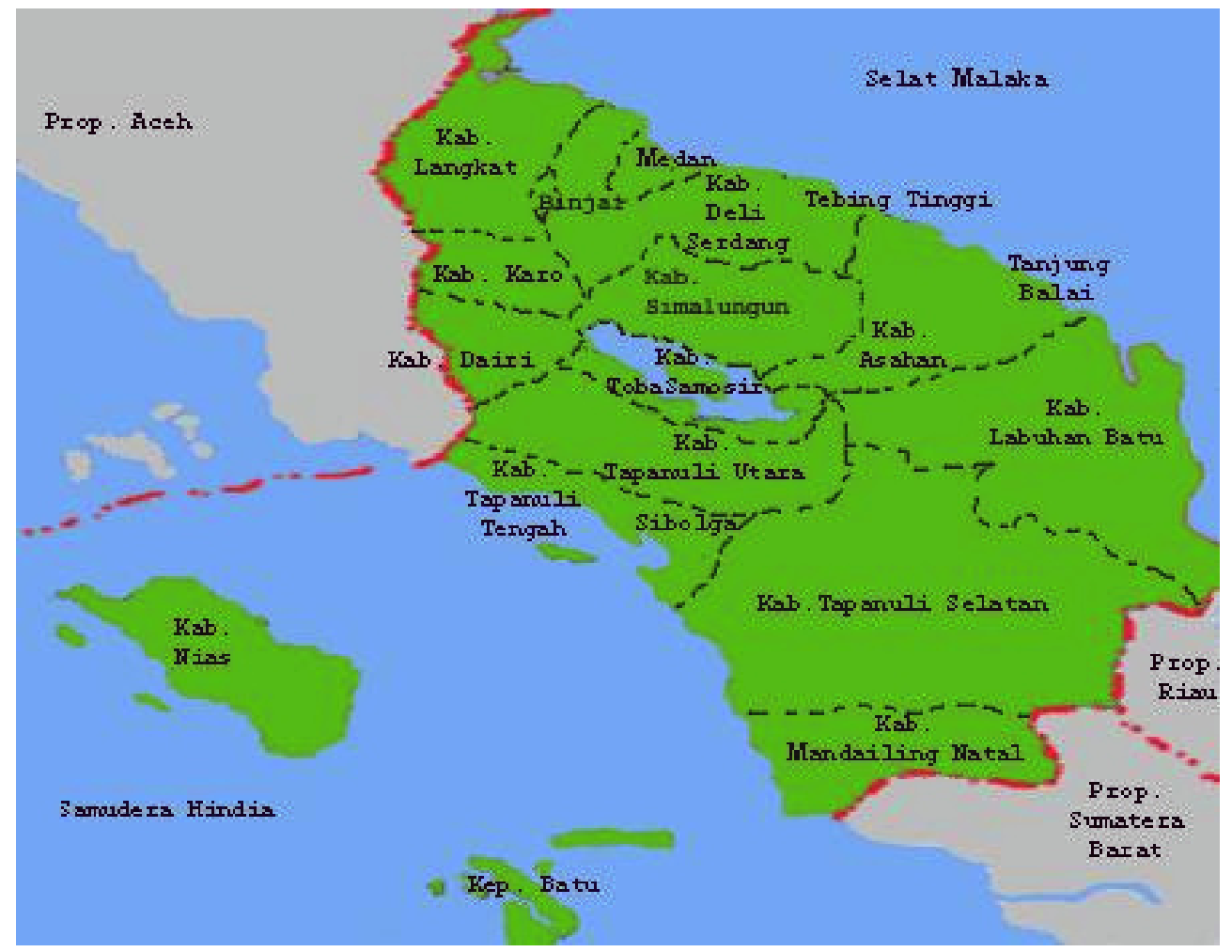

Figure 1. Province North Sumatra.

That the concept of Taneh Karo can be traced back to pre-colonial times is shown in scholarly literature ${ }^{1}$ as well as in a Karo myth entitled Turi-turin Rumah Si Pitu Ruang (The myth of the house of seven spaces). While I have heard the myth being told many times during my childhood, field research ${ }^{2}$ on the Karo house (1989-1990) has stimulated me to make a special study of this myth.

The research of the myth started when we investigated a Karo ritual called putar, performed during the inauguration of a house. Putar ${ }^{3}$ is a body paint that is mainly put on the face, but sometimes on the hands and feet as well. The paint is made of a mixture of rice powder, water and kunyit, put on one's skin using a stalk of the lulang shrub (Ind. jarak) as a pencil. When we asked

See Anderson 1971 [1826]; Halewijn 1876; Ginting 2003.

2 Field research was conducted together with Beatriz van der Goes from Leiden University.

3 Literally means turning around. 
about the relevance of this ritual to the inauguration of a house, most of our informants said that it can be traced to the origin of the Karo house (rumah) as described in the myth of the House of Seven Spaces.

Although I knew the text of the myth very well it was difficult for me to understand this explanation. It forced us to make a thorough study of the myth. We started by recording the myth from different storytellers and asking the storytellers what they considered to be the relevance of the myth.

In this paper I examine the relevance of the myth. I argue that the myth is not only relevant for understanding traditional ways of life as practiced by the Karo until the present day, but that it is even more important to inter-group relations in the region involving in particular the Aceh, Batak as well as the Malay people living on the east coast and on the coast of Sumatra. The myth marks a difference between the lands oriented towards the western oceanic shore with the port of Barus as its centre, and those oriented towards the eastern shore with the port of Deli as its centre. It places Karo society and land in a special position in this inter-group network, a position which becomes the outset of the Karolands.

\section{THE MYTH}

Beru Buaten (BB), the daughter of Sibayak Ajinembah (SA), went to collect firewood in the forest near the village of Ajinembah. There she met Raja Umang (RU). RU proposed to marry her. She agreed but on the condition that RU would build a house of seven spaces for her father, SA. RU agreed with the condition.

Several days later, the inhabitants of Ajinembah heard the sounds of the construction of house during the night. The sounds indicated that many people were working to build the house. However, they could not see the building process. The same sounds were repeated for seven nights. On the day following the seventh night, the inhabitants of Ajinembah saw a newly built house: The house of seven spaces. They realized now that the sounds they had heard were made by umang (half human, half spirit) that had built the house.

The time of the inauguration of the house coincided with the wedding day of BB and RU. However, the inauguration of the house and the wedding were in different places. Inside the house, the bride-giving party performed the inauguration of the house, while the bride-taking party performed the wedding outside the house with a Toba Batak orchestra (gendang teba). SA's wife who was inside the house with the bride-giving party was interested in the orchestra and came to see the wedding. Then the bride-taking party stopped the wedding and left Ajinembah. The bride and bridegroom fled to the top of Mountain Sibuaten and live there till today.

Now, the inauguration of the house turned into chaos. The guests entered the house through the downstream entrance. They took a lunch, dinner or breakfast and then left the house through the upstream entrance. This was done repeatedly for several days, so that SA had to slaughter all his cattle to 
feed the guests. The only cattle left in the village of Ajinembah were a pair of male and female Nanggalutu buffaloes owned by his son, Raja Sori (RS). These buffaloes were huge. Eight people could sit on their back while playing chess. In despair, SA slaughtered the male Nanggalutu buffalo and offered the meat to the guests.

RS was very angry hearing this. He took his knife and planned to kill his father. But his mother prevented this. She sent him to his mother's brother who was the king of Raya. On his way to Raya, RS rode the female Nanggalutu buffalo, accompanied by seven male servants. On the road, the servants assaulted RS. They forced him to step down from the back of the buffalo and to be their servant instead of the other way around.

The king of Raya received the so-called princes as his sister's sons and RS as their servant. But he wondered why the servant behaved like a prince and the princes like a servant. He asked the so-called princes to unsheathe the knife left behind by SA some years ago. None of them was able to do it. When the king of Raya asked RS to try it too, he could easily unsheathe the knife because it was his father's knife.

Now the king of Raya was sure which one of the men was his sister's son. He planned to marry off RS to one of his seven daughters. The daughters competed with each other for RS's attention. Through divination, the youngest daughter was appointed to marry RS.

The king of Raya asked RS what would be the preferred part of the domain of Raya he wished to receive as a wedding gift. RS answered: "The domain should be as large as the land circled by this rope". He showed a rope made of the skin of the female Nanggalutu buffalo. Apparently he had killed the buffalo and twined a rope from its skin. The land encircled by the rope was as large as the entire domain of Raya.

Since then the land of Raya became the domain of the Seragih clan founded by RS. Before this, the land of Raya was the domain of the Purba clan. The former king of Raya, who was RS's wife's father, belonged to the Purba clan. Then the Purba clan moved out and established itself a new domain.

Now let us return to Ajinembah. The chaos did not come to an end. SA had nothing left to be offered as meat to the guests. He went to a bathing place located at the bank of the river that crossed Ajinembah. He washed his face. The water surface mirrored the image of Sibayak Barus Jahe (SBJ) standing behind him. He was accompanied by his sister who was also his lover. Because of this forbidden love, they had been banned from Barus.

SBJ asked SA about the worries he had as these could be told by the look on his face. SA informed him about the inauguration of the house that had turned into a chaos. SBJ promised to solve the problem by means of ritual.

SBJ made tepung tawar and applied it as putar upon each guest who entered the house through the downstream entrance. The reaction was remarkable. As if just woken up from a deep sleep, the guests suddenly realized there were many more things to do in daily life than repeatedly entering the house for breakfasts, lunches, and dinners. SA was very thankful to SBJ and accepted 
him as his kalimbubu (bride giver). He allowed SBJ to found a part of Si Pitu Kuta urung into the domain of Sibayak Barus Jahe. All Karo houses trace their origin to this myth.

\section{GEOGRAPHICAL SETTING OF THE MYTH}

The myth states different places: Ajinembah, Mountain Sibuaten, Raya, Si Pitu Kuta, and Barus Jahe. All these places still exist today and are well known to most Karo. Below I shall describe them in order to give a clearer insight into the circumstances of the myth.

\section{The village of Ajinembah}

Today, the Karo mostly know Ajinembah as one of villages (kuta) situated in the district of Tigapanah (Kecamatan Tigapanah) (Karo regency). Tigapanah is the main village of this district.

A Karo village ( $k u t a)$ constitutes of an area called a rumah kuta (literally; a village's house). People may build different houses (rumah) as well as rice granaries (sapo page), charnel houses (geriten), sleeping places for unmarried men (jambur), and rice pounding places (lesung) within the rumah kuta. A bamboo fence usually encircles these buildings in order to set the rumah kuta apart from the rest of the village's land.

Traditionally, people may only build customary houses (rumah adat) within the rumah kuta. A Karo customary house consists of different sections (jabu), the number of which may vary from four, six, eight, twelve, sixteen to twenty four. Each of the sections is assigned to a family (also called jabu) (see Picture 1).

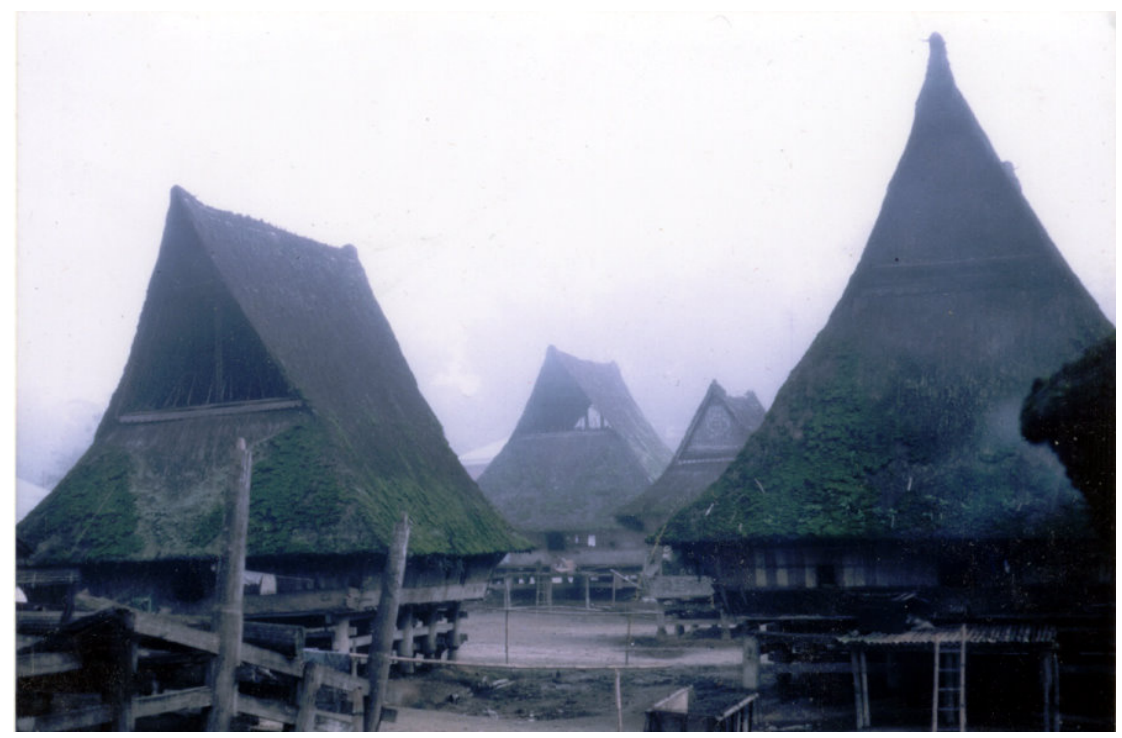

Picture 1. The rumah kuta of Dokan village; Photograph by the author, 1990. 
Si Pitu Kuta "Urung"

During the colonial time, Ajinembah became the capital village of an urung named Si Pitu Kuta Ajinembah.

As said above, urung is a particular land founded by a clan. An urung encompasses different villages. Most of the villages in the same urung are founded by the clan that founded the urung, but other clans may found a village within the urung as well. The other clans must relate as anak beru or senina to the founder of the urung. Anak beru refers to one's bride taker and senina to someone else who has the same relation as one self toward a third person. One and his/her senina relate as bride taker or bride giver (kalimbubu) to the third person.

A Karo clan (merga) is patrilineal and patrilocal. People belonging to same clan relate to each other as sembuyak (same womb). Marriage within same clan is strictly forbidden. Different clans may originate in the same clan by means of patrilineal descent-line, but they relate to each other as senina since they represent different urung. Karolands are divided into the domains of different urung each of which represents the clan that founded it.

Si Pitu Kuta Urung mentioned in the myth is one among other Karo urung. The appearance of this urung in the literature is quite unique. Some earliest literature on the Karo mentions Barus Jahe as the capital village of Si Pitu Kuta Urung founded by the Barus clan. Later literature on the Karo seems to realize that Si Pitu Kuta is the name of a land encompassing three different urung: Si Pitu Kuta Barus Jahe Urung founded by the Barus clan, Si Pitu Kuta Tongging Urung founded by the Munte Tongging clan and Si Pitu Kuta Ajinembah Urung founded by the Munte Ajinembah clan. Barus Jahe, Tongging, and Ajinembah are respectively the names of the capital villages of these urung, which differentiate the urung from each other although they carry the same name of Si Pitu Kuta.

Our myth's text describes Si Pitu Kuta Urung as centred in Ajinembah village. After SBJ had made an end to the chaos in The House of Seven Spaces, SA offered a part of Si Pitu Kuta Urung to be founded by SBJ into the domain of Sibayak Barus Jahe.

\section{Sibayak Barus Jahe}

Sibayak refers to a land encompassing different urung. The chief of the land is also titled sibayak. Therefore, Sibayak Barus Jahe may mean a particular land or the chief of this land depending on the context. Barus Jahe is the name of the land which derived from the name of its capital village. Barus Jahe thus becomes the names of a village, an urung and a sibayak.

It is quite interesting that the myth gives the title sibayak to Sibayak Ajinembah (SA) though Ajinembah never appears as a sibayak land. During the colonial time, Ajinembah became the capital village of Si Pitu Kuta Ajinembah Urung. The chief of this urung was titled raja urung just like other urung chiefs.

The title sibayak given to Sibayak Ajinembah insinuates the specific position 
of Si Pitu Kuta Urung among other Karo urung. As an urung becomes part of a sibayak land, the chief of an urung (raja urung) has a lower position than the chief of a sibayak land (sibayak). The myth seems not to place Sibayak Ajinembah in a lower position than other Karo sibayak. I will return to this.

\section{Karo-Simalungun relationship}

The myth describes the movement of Raja Sori (RS) from Ajinembah to Raya after his father had slaughtered the male Nanggalutu buffalo. This movement connects not only the lands of Ajinembah and Raya as bride-taking and bride-giving parties; it also connects the Karo to the Simalungun in terms of inter-clan relationship. Raja Sori becomes the ancestor of the Seragih clan and replaces his mother's brother as the chief of nagori Raya. From then on the land of nagori Raya no longer belongs to the Purba clan, it has become the land of the Seragih clan.

The Simalungun term nagori refers to an area comparable to the Karo term urung. The region named nagori Raya is situated within Simalungun with Pematang Raya as the main village. Conversely, the urung named Si Pitu Kuta is situated in Taneh Karo.

\section{Mount Sibuaten}

Mount Sibuaten is the highest mountain in Taneh Karo. The village of Ajinembah is located at the foot of this mountain. According to the myth, Raja Umang (RU) and Beru Buaten (BB) are living on the top of this mountain.

To the Karo People, the mountain is a significant marker in dry-rice cultivation. Traditionally, Karo farmers mark a spot as the centre of a rice field by planting some medicinal plants, which is called the field's navel (pusung juma) or starting point (pemenan). This spot becomes the locus of the rice spirit called Beru Dayang. Before starting to sow rice, Karo farmers offer a blade of betel leaf on this spot. ${ }^{5}$

All over Taneh Karo, people must direct that betel leaf to Mount Sibuaten. However, there is a difference in the direction of the betel leaf between East and West Karo. In east Taneh Karo, the stalk of the betel leaf points towards Mount Sibuaten. In west Taneh Karo, it is the tip of the betel leaf that points towards Mount Sibuaten.

A similar contrast occurs with respect to the traditional Karo customary house (rumah adat). The house has two entrances connected by a gulley (labah or anak lau). The gulley constitutes a line connecting the jahe and julu sides of the house. In east Taneh Karo, Jahe and Julu refer to the flow of water, that is downstream and upstream parts of a river that crosses the lands of a village. In west Taneh Karo, Jahe and Julu refer to the direction of sunset and sunrise, which are west and east.

Mount Sibuaten has a crucial position in those contrasts. The mountain looks like two mountains that are joined as it has two tops. One of the tops is situated in eastern Taneh Karo, the other in western Taneh Karo. The name

$5 \quad$ See Van der Goes 1997. 
sibuaten indicates its position in connecting eastern and western Taneh Karo. It literally means "to take each other".

\section{West and east coasts of Sumatra}

The Karo also consider the myth about the origin of the Karo house as the myth about the origin of the Barus clan by telling how Sibayak Barus Jahe (SBJ) becomes the ancestor of this clan who founds the land named Sibayak Barus Jahe.

The domain of Sibayak Barus Jahe is not restricted to the Karo Highlands. It extends to the eastern part of Downstream Karo (Karo Jahe), which in the literature is usually referred to as Upper Deli. The part of the land of Sibayak Barus Jahe that extends into Upper Deli is called Urung Sinembah. The name, reminding of Ajinembah, indicates that the domain of Si Pitu Kuta extends into Upper Deli since the domain of Sibayak Barus Jahe represents a part of the domain of Si Pitu Kuta.

Deli is a Malay kingdom on the east coast of Sumatra. The domain of Deli is divided into Downstream Deli (Deli Hilir) and Upstream Deli (Deli Hulu). Downstream Deli consists of four Malay kejuruan and Upstream Deli of four Karo urung. Kejuruan is a Malay term comparable to Karo urung.

According to the myth, Sibayak Barus Jahe (SBJ) came originally from Barus, a Malay kingdom on the west coast of Sumatra. The inclusion of Urung Sinembah into the domain of Deli is relevant for the position of Ajinembah in a trade network involving the Barus and Deli Malay kingdoms. It points at the camphor-benzoic routes that existed between the eight and fourteenth centuries, connecting the interior Batak domains to the ports of Barus on the west coast and Kota Cina in Deli on the east coast, from where the goods were exported to China (Andaya 1995: 387). From the fifteenth century onwards the port of Deli rose in importance due to the production of black pepper that was cultivated at Upstream Deli by Karo farmers. The Karo consider Upstream Deli as Downstream Karo. The myth indicates how Si Pitu Kuta Urung became included within this larger network.

\section{THE ORDER OF THE TRADITIONAL KARO HOUSES}

\section{Raja Berempat}

A traditional Karo house consists of several (jabu), from four (empat jabu), six (enem jabu), eight (waluh jabu), twelve (sepuludua jabu), sixteen (sepuluenem jabu) to twenty four (dua puluh empat jabu). These sections are classified either as corner or as central sections. The four sections situated in the four corners of the house are called corner sections (jabu suki), and the rest are central sections (jabu tengah). As the central sections may be considered to be part of one of the four corner sections, all traditional houses represent the house of four sections (rumah si empat jabu), in spite of the variation in the number of sections.

The four corner sections are named "the base of the tree" (bena kayu), "the top of the tree" (ujung kayu), "the other side of the base of the tree" (lepar 
bena kayu), and "the other side of the top of the tree" (lepar ujung kayu). They are assigned to four families (jabu) that represent four different clans. How these relate to each other is expressed by the terms sembuyak (the clan of the founder), anak beru (the clan of the founder's bride taker), kalimbubu (the clan of the founder's bride giver) and senina (the clan that has same relation as the clan of the founder towards a third clan). The section of "the base of the tree" is assigned to the sembuyak, the section of "the top of the tree" to the anak beru, the section of "the other side of the base of the tree" to the kalimbubu and the section of "the other side of the top of the tree" to the senina (Figure 2).

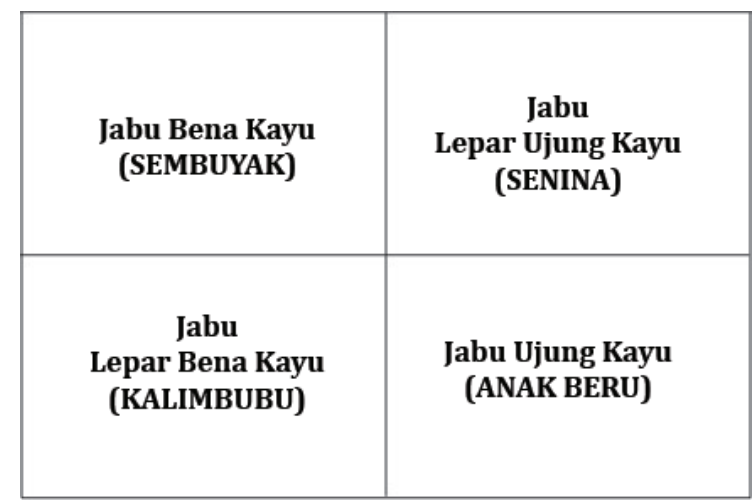

Figure 2. The four sections of the Karo house.

This relationship between clans was also applied in the institution called raja berempat (four kings). There were four different institutions of raja berempat in Karo society: 1) the raja berempat of the Eastern Karo Highlands, 2) the raja berempat of the Western Karo Highlands, 3) the raja berempat of the Deli Malay kingdom, 4) the raja berempat of the Langkat Malay kingdom.

The raja berempat of the Eastern Karo Highlands consisted of Sibayak Barus Jahe (Barus clan), Sibayak Lingga (Sinulingga clan), Sibayak Sarinembah (Milala clan), and Sibayak Suka (Suka clan). The raja berempat of the Western Karo Highlands consisted of Sibayak Kutabuluh (Kutabuluh clan), Sibayak Bangun Mulia (Bangun clan), Sibayak Perbesi (Sebayang clan), and Sibayak Taneh Pinem (Pinem clan). The four sibayak of one raja berempat relate to each other in terms of sembuyak, anak beru, kalimbubu and senina. In this way, each of the Eastern and Western Karo Highlands represents a customary house.

Each of the raja berempat of the Deli and Langkat Malay kingdoms consisted of two Karo urung and of two Malay kejuruan. The sultan of Deli became the chief of the raja berempat of the Deli Malay kingdom and the sultan of Langkat was chief of the raja berempat of the Langkat Malay kingdom. Like the raja berempat of the Eastern and Western Karo Highlands, the urung and kejuruan of these raja berempat relate to each other in terms of sembuyak, anak beru, kalimbubu and senina. Though these terms are apparently of Karo origin, the families of the Deli and Langkat sultanates still use them in their rituals. 


\section{East and West Karolands}

The raja berempat of the Eastern and Western Karo-Highlands occurred not only for Eastern and Western Karo-Highlands. They represent two houses that encompass the entire Karolands. This can be related to the division of Karolands into the Karo Highlands (Karo Gugung) and Downstream Karo (Karo Jahe).

Karo Highlands and Downstream Karo relate to each other as respectively representing the place of return (kemulihen) and beyond the village's house (perlajangen). The same relation occurs between the village's house (rumah kuta) and village's lands (taneh kuta) of a same village. Rituals performed within the village's house relate people to each other by means of the terms sembuyak, anak beru, kalimbubu and senina. Conversely, rituals performed in the village's lands relate people to each other as a clan's people.

That relation between the village's house and the village's lands occurs in every Karo village situating either in the Karo Highlands or in Downstream Karo since each Karo village is marked by a village's house surrounded by an agricultural-herding area representing the village's lands. It is applied to the relation between the Karo Highlands and Downstream Karo not to state the Karo Highlands as the homeland of the Karo and Downstream Karo as their migration land, as assumed by the colonial officers, but rather it concerns with the relation between urung (see below).

There are four Karo urung in Eastern Downstream-Karo and four other Karo urung in Western Downstream-Karo. Two of the four Karo urung in Eastern Downstream-Karo include within the raja berempat of the Deli Malaykingdom, and two of the Karo urung in Western Downstream-Karo within the raja berempat of the Langkat Malay-kingdom. However, there is no direct inter-relationship among the Karo Downstream urung. Relations are based on their inclusion within the raja berempat of Eastern Karo-Highlands or the raja berempat of Western Karo-Highlands. It corresponds to a mythical idea that two countries (negeri) share the Karolands: Sun-rising (Negeri Kepultaken) and Sun-setting Countries (Negeri Kesunduten). The raja berempat of Eastern-Karo Highlands represents the Sun-rising Country and the raja berempat of WesternKaro Highlands the Sun-setting Country. Like a Karo village, each of the countries constitutes a house and a land. Eastern-Karo Highlands represents the house of the Sun-rising Country and Eastern Downstream-Karo its land. Western-Karo Highlands represents the house of the Sun-setting Country and Western Downstream-Karo its land.

That mythical idea needs not to be confronted with the fact that every Karo village constitutes a village's house and a village's land so the differentiation of the house from the land occurs everywhere in the Karolands. We need to place it in the pre-colonial context when the Karo produced black pepper and millet at a large scale in Downstream Karo. Black pepper and millet were not produced for their own consumption, but traded to the world outside. They sold black pepper particularly to Malacca and millet to European and Arabic shippers who needed millet for their food. The farmers of these products were 
not mainly Karo inhabitants of Downstream Karo. Several inhabitants of the Karo Highlands developed black pepper fields and millet in Downstream Karo. These Karo Highlanders continued to reside in villages in the Karo Highlands although they mostly dwelled in Downstream Karo.

Each of Downstream Karo's urung relates as senina to a Karo Highland's urung so they have access to a Karo Highland's raja berempat. Downstream Karo urung relate to each other following their inclusion within a Karo Highland's raja berempat. In this way, the raja berempat of Eastern Karo-Highlands and that of Western Karo-Highlands respectively represent Sun-rising and Sunsetting Countries encompassing the entire Karolands.

\section{THE ORIGIN OF THE KARO RAJA BEREMPAT}

The raja berempat of the Eastern Karo-Highlands is constituted of the Sibayak of Barus Jahe, Lingga, Suka, and Sarinembah. Sibayak Barus Jahe is the main point of reference in the relation between these four sibayak, which makes him the main point of reference in the relation between the urung of Eastern Karo. Likewise, the raja berempat of the Western Karo-Highlands is constituted of the Sibayak of Kutabuluh, Bangun Mulia, Perbesi, and Taneh Pinem. Sibayak Kutabuluh becomes here the main point of reference in the relation between these four sibayak, and as such he is the main point of reference in relation between the urung of Western Karo.

In turn, both, the Sibayak of Barus Jahe and of Kutabuluh have a specific relation to the Si Pitu Kuta Ajinembah urung. According to the myth, Sibayak Ajinembah offered a part of the land of the Si Pitu Kuta Urung to Sibayak Barus Jahe. The position of Sibayak Barus Jahe, as the main point of reference in the relation between the urung of Eastern Karo, indicates at a the part to a whole' relation between the Si Pitu Kuta Urung and Eastern Karo. As still can be observed today, the Si Pitu Kuta Urung is located in Eastern Karo by which it stands out as a part of Eastern Karo. However, as delineated by the myth, this part represents Eastern Karo as a whole.

Sibayak Kutabuluh also relates as a part to the Si Pitu Kuta Urung. This relation can be traced to the myth about the origin of Sibayak Kutabuluh. According to the myth, the founder of Sibayak Kutabuluh stems from Kacinambun village. This village is located in the land of the Si Pitu Kuta Ajinembah urung. The village has been founded by the Kacinambun clan who relate as anak beru (bride taker) to Sibayak Ajinembah. The myth about the origin of Sibayak Kutabaluh delineates Sibayak Kutabuluh to relate to Sibayak Ajinembah in a similar way as Kacinambun village relates to the Si Pitu Kuta Urung, which also constitutes a 'the part to a whole' relation. As Sibayak Kutabuluh is the main point of reference in the relation between the urung of Western Karo, West Karo also relates as part to the Si Pitu Kuta Urung.

This shows us that the Si Pitu Kuta Urung is a part of the Karolands that represents the Karolands as a whole. It relates East Karo and West Karo to each other in representing two different parts of the Si Pitu Kuta Urung. 
THE ARCHAEOLOGY OF THE MYTH

\section{The foundation stones}

Neither the myth nor the Karo are able to present information about what the house of seven spaces might have been. In spite of this, most of the Karo know that the foundation stones (palas) of the house can still be found in Ajinembah village. The foundation stones stand side by side in an order similar to the foundation stones of the Karo customary houses (rumah adat). However, the foundation stones are natural stones and far larger in size than those of the Karo customary houses. One may wonder how the stones could have reached the place, as there is nothing nearby that could have been the source of the stones (see Picture 2 and Figure 3).

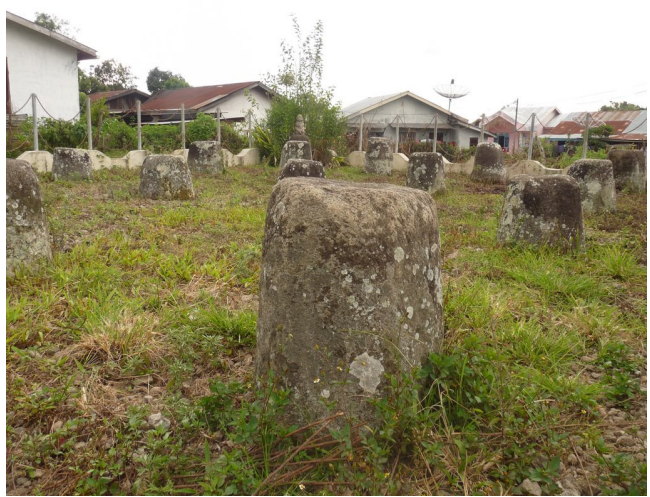

Picture 2. The foundation stones of the house of seven spaces; Photograph by the author.

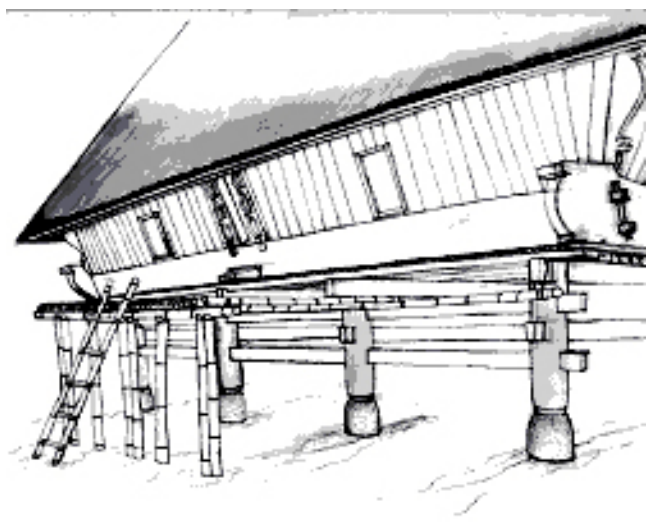

Figure 3. The foundation stones of a Karo customary house.

According to the myth, the house of seven spaces was built by umang under the order of Raja Umang (the chief of umang). To the Karo, umang are "half human, half spirit". They are mostly invisible to the eyes of human beings, but, in some cases, they may show themselves to human beings. The body of an

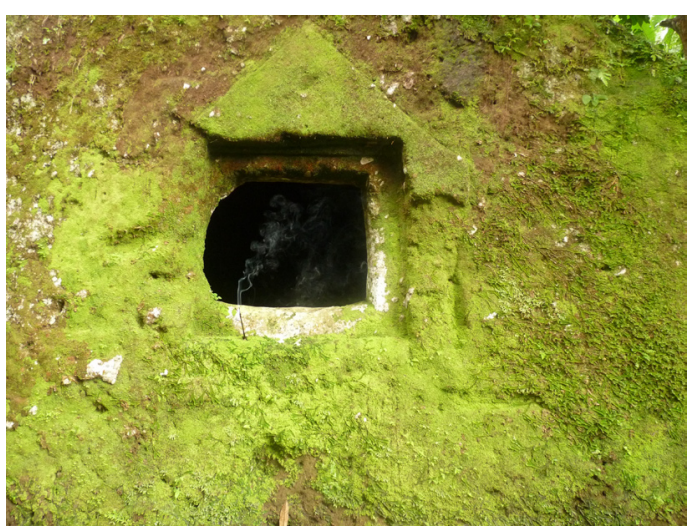

Picture 3. The entrance of Gua Umang; Photograph by the author. adult umang is as large as the body of a human child. The feet of umang are turned backwards so that their footprints indicate an inversion in the direction of walking. They prefer to live in the 'old forests' covering the top of mountains. They live like humans in families of parents and children. Their houses are carved out of stone. Normal human beings cannot see the houses they are still using, but people are able to see the houses 
that are out of use. Several of such stone caves (gua umang) can be found in the Karolands, but not beyond it (see Picture 3).

Up to today, no archaeological study has identified the age of the foundation stones neither the age of the carved-stone caves called gua umang.

\section{The Karo-Gayo connection}

According to the myth, Sibayak Ajinembah's son had a pair of Nanggalutu buffaloes. Another version of the myth expresses that the giant water buffaloes stem from the Gayolands (Southern Aceh). A wide ravine connecting Bambil (a place in the Gayolands) and Ajinembah is said to be the trace of the giant water buffaloes that repeatedly visited Ajinembah and vice versa. Many villages located along the ravine track are founded by the Munte clan including those that are part of the Gayolands. Therefore, Gayo people who belong to the Gayo clan of Munte trace their origin to the Karolands. On the other hand, some members of the Karo clan of Munte trace their origin to Bambil. The name of Bambil is used as a male first name among the Karo members of the Munte clan.

The giant water buffaloes point at another network of the Si Pitu Kuta Urung, connecting as such Karo and Gayo to each other. The network becomes manifest in the pre-colonial trade of water buffaloes from the Gayolands to Deli via the Karolands, using the ravine as the main road. The house of seven spaces (rumah si pitu ruang) confirms this network, as the name is a reference to the Gayo's ume si pitu rue (the Gayo's pronounciation of rumah si pitu ruang).

\section{In between Batak and Malay}

The inauguration of the house takes place at the same time as the wedding of Raja Umang (RU) and Beru Buaten (BB), but in different places. The former belongs to the bride-giving party, and the later to the bride-taking party. During the wedding, the bride-taking party plays a teba orchestra. This passage sets Si Pitu Kuta Urung apart from the Batak. Teba is a Karo term for what we know now as the Batak. The bride-taking party stopped their ritual when the bride's mother came to the wedding. They left the wedding at an incomplete stage.

The incompleteness of the wedding causes the inauguration of the house to remain unfinished. It was Sibayak Barus Jahe (SBJ) who could finish the inauguration of the house by performing the putar. The same kunyit (Curcuma domestica) coloured rice-paste is known as tepung tawar among the Malay. They use tepung tawar to welcome a married couple into the house. The house members print the mixture onto the palms of the couple's hands. Among the Karo, the paste aims to separate members of a new house from those of their former house in marking the mixture on their cheeks and forehead. If applied on feet and hands it is never on the inside. According to the Karo, putar roots in the Malay tradition, but the word putar (turning around) indicates an inversion of the Malay tradition. This can be traced to an earlier passage of the myth that indicates the inclusion of Si Pitu Kuta Urung within the Deli 
Malay-kingdom.

The chaotic situation at the inauguration of the house causes a separation of Si Pitu Kuta Urung from the Batak. The putar brings a new order to the house, but reverses Si Pitu Kuta Urung from the Malay kingdom. It delineates the Karolands to locate in between the lands of the Batak and the Malay.

\section{CONCLUSION}

The myth states the special position of the Si Pitu Kuta Urung, the differentiation of Karolands into villages, urung and sibayak, as also the division of the lands into east and west Karo, which is applied by the people in the orientation of their settlements and the relation between the settlements. The foundation stones of the house of seven spaces in Ajinembah village connect its mythical perception to the practice of house building and rice cultivation.

As delineated by the myth, the special position of Si Pitu Kuta Urung can be traced to its position in representing the Karolands as a whole. Although Si Pitu Kuta Urung is a part of the Karolands it represents the Karolands as a whole towards the surrounding world such as the Batak, Malay, Simalungun and the Gayo. In representing the Karolands as a whole, the other parts of Karolands are considered as parts of Si Pitu Kuta Urung.

\section{REFERENCES}

Andaya, Barbara Watson. 1995. “Upstream and downstream in early modern Sumatra". The Historian 57/3: 537-552.

Anderson, John. 1971 [1826]. Mission to the east coast of Sumatra in 1823. Kuala Lumpur/New York: Oxford University Press.

Ginting, Juara R. 2003. “Inter-group relations in North Sumatra”, in: Geoffrey Benjamin and Cynthia Chou (eds), The tribal communities in the Malay world: Historical, cultural and social perspectives, pp. 384-400. Singapore: Institute of Southeast Asian Studies.

Van der Goes, Beatriz A. 1997. "Beru Dayang; The concept of female spirits and the movement of fertility in Karo Batak culture", Asian Folklore Studies 56/2: 375-405.

Halewijn, E.A. 1876. “Geographische en ethnographische gegevens betreffende het Rijk van Deli (Oostkust van Sumatra)", Tijdschrift voor Indische Taal-, Land- en Volkenkunde 23: 147-158. 